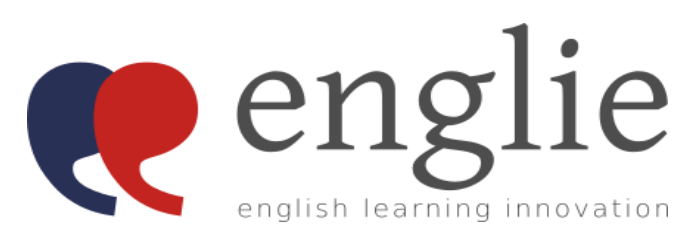

Vol. 3, No. 1 February 2022

P-ISSN: 27237400

E-ISSN: 2723 - 7419

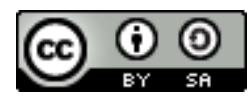

This is an open access article under the CC-BY-SA license

\title{
"Your Next Stay Will Be on Us": Genre Analysis of Hotel Responses to Negative Reviews
}

\author{
Cita Nuary Ishak \\ English Department, Politeknik Negeri Malang, Indonesia \\ Corresponding Author: citanuary@gmail.com
}

\begin{abstract}
The purpose of the present paper is to identify the typical moves, steps, and common expressions in hotels' responses to negative reviews (RNRs) posted on TripAdvisor. A specialized corpus comprising authentic 29 responses, written by top seven 4- and 5-star hotels in Malang was explored by following Swales' notion of move analysis. Corpusassisted analysis was also applied to identify some frequent expressions typical to major moves. The findings revealed that the generic structure of RNRs written by top hotels in Malang contain six moves and 23 steps. Unique to this finding are four additional steps that were distinct from previous studies, but appeared in the corpus: appreciating the stay, promoting hotel's facility, clarifying misunderstanding, and making amends. 'Thank you for' (appearing 30 times in 22 responses) were among the most frequent expressions in major moves such as appreciating the stay and expressing gratitude. Other common expressions were also identified from the corpus and used as the basis of proposing a brief guideline for composing RNRs, which can be useful for teaching business English, or English for Specific Purposes. Overall, these findings outline a generic pattern through which representatives of top hotels in Malang manage customers' dissatisfactions and complaints. Since these findings were derived from naturaloccurring data, they can also be useful to classroom instructions, especially in providing authentic materials.
\end{abstract}

Keywords: genre analysis, hotel responses, move-step approach, negative reviews

\section{ABSTRAK}

Artikel ini bertujuan untuk mengidentifikasi Tahapan-Langkah (move-step) dan ungkapan yang umum digunakan dalam respon hotel terhadap ulasan negatif di situs TripAdvisor. Data penelitian berupa 29 respon dari tujuh hotel berbintang 4 dan 5 yang berlokasi di Kota Malang. Analisis move secara umum mengikuti kerangka analisis Swales dan analisis frekuensi ungkapan menggunakan analisis korpus. Hasil analisis menunjukkan struktur respon hotel terhadap ulasan negatif terdiri dari 6 tahapan dan 23 langkah. Di antara 23 langkah ini, terdapat 4 langkah yang berbeda dari temuan kajian terdahulu, yaitu: appreciating the stay, promoting hotel's facility, clarifying misunderstanding, dan making amends. Ungkapan 'Thank you for' yang muncul 30 kali di 22 respon merupakan salah satu ungkapan yang paling umum digunakan, khususnya pada tahapan appreciating the stay dan expressing gratitude. Ungkapan umum yang digunakan pada setiap tahapan-langkah juga diidentifikasi dan disajikan dalam bentuk ringkasan untuk dapat digunakan sebagai salah satu pedoman untuk menyusun respon 
terhadap ulasan negatif, yang juga dapat bermanfaat untuk pengajaran Bahasa Inggris untuk bisnis dan tujuan khusus. Secara keseluruhan, tulisan ini mengidentifikasi pola umum tahapan-langkah beserta ungkapan umum yang digunakan dalam respon hotel berbintang 4 dan 5 dalam menanggapi ketidakpuasan dan keluhan pelanggan di media daring, yang juga diharapkan dapat bermanfaat sebagai salah satu pilihan materi pembelajaran yang otentik dalam pengajaran Bahasa Inggris.

Kata Kunci: analisis genre, respon hotel, analisis tahapan-langkah, ulasan negatif

\begin{tabular}{c|c|c} 
Received: January 26, 2022 & Accepted: February 8, 2022 & Published: February 9, 2022 \\
How to cite:
\end{tabular}

Ishak, C.N. (2022). "Your Next Stay Will Be on Us": Genre Analysis of Hotel Responses to Negative Reviews. English Learning Innovation, 3(1). 1-15. https://doi.org/10.22219/englie.v3i1.19795

\section{INTRODUCTION}

How customers make purchasing decisions is greatly influenced by the emergence of online platforms and user-generated review features (Thumvichit \& Gampper, 2019). The review sections containing customers' honest feedback are the "first stop" (ibid, 2019: 2) for planning their travel, helping them to choose where to stay on holiday or where to dine in a foreign city (Napolitano, 2018). Hence, the review sections in online platforms are helpful for customers, because other customers' past experiences may assist them in making decisions about their planning and itineraries.

Not only for customers, it is also imperative for business providers to "stop by" the review sections and give their responses, especially to the negative ones. This is because quality responses to online customer reviews may help increase sales. An empirical study on the relationship between responses and online customer reviews conducted by Liu et al (2020) revealed that seller responses to customer reviews, particularly the negative ones, has a significant positive effect on sales. RNRs directly address problems and hence customers can dispel their doubts, give their trust, and proceed to the next steps, such as purchasing products or booking a service.

In hotel industry, managing negative reviews, especially the ones that are posted online, is necessary for hotel management for maintaining the hotel image (Geetha, Singha, $\&$ Sinha, 2016). Thus, majority of top hotels appoint employees in senior positions to handle negative comments, because the spread of unfavourable reviews may harm hotel image and reputation (Panseeta \& Todd, 2014). Having longer years of experience in dealing with customer complaints, it is expected that senior hotel staff can give a proper response to the negative comments. With electronic reviews spreading quickly, hotel image can be advantaged or harmed (Thumvichit, 2016). For example, prospective customers might avoid 
booking a hotel because of several negative comments from past customers, and they might immediately book a hotel after reading some positive reviews.

The fact that hotels assign representatives to write RNRs "indicates that the hotels do pay attention to customers' satisfaction and quality of their services" (Thumvichit, 2016, p. 2). For such hospitality business, responses to complaints are critical to customer relationship management (Napolitano, 2018). Thumvichit (2016) and Napolitano's (2018) remarks reminds me of an online guest lecture I attended in December $13^{\text {rd }}, 2021$. The keynote speaker was a director of a prestigious, five-star hotel in Jakarta, which belongs to one of the biggest hotel chains in Indonesia. In his talk, he highlighted the importance for making the time to, not only read, but reply to each comment written by their customers. He also mentioned that it is their routine to start the day by reading the comments about their hotel, and to focus on the areas that need improvement. From his talk, it can be inferred that online review also benefit hotel businesses. They offer comparative insights about customer satisfaction (Mauri \& Minazzi, 2013). They are also the means through which customers express their dissatisfaction, inform business providers which aspects they lack of, and give honest reviews about services that they experience. Therefore, this particular section is of high importance not only for customers but also hotels because it informs hotel management team the areas that needs attention and improvement.

Being highly significant to business providers, RNRs have received much attention. Several studies of RNRs that focused on genre analysis have been conducted by, among others, Zhang \& Vásquez (2014), Panseeta \& Todd (2014), and Thumvichit \& Gampper (2019). One similarity among these studies is that they all follow Swales' notion of move analysis. As suggested by these studies, several generic structures of RNRs have been proposed. The study by Zhang \& Vásquez (2014) aimed for an identification of the generic structure of responses written by hotels in four popular tourist destinations in China. Their study investigated 80 replies by the hotels in TripAdvisor and found that there are ten move types commonly found in the genre. The results suggest that online RNRs tend to be formulaic, with moves such as thanking and apologizing to be some of the most common moves identified.

The study done by Panseeta \& Todd in the same year investigated hotel RNRs to identify generic patterns and most frequently used expressions and lexical choices. Their study looked at a corpus of 100 replies written by 20 hotels in Thailand. They found that the hotel responses consisted of five moves, namely, opening, acknowledging feedback, dealing 
with complaints, closing remarks, and ending. Each move has several distinctive steps, each with its own communicative functions.

From the generic structure outlined by Panseeta \& Todd (2014), Thumvichit \& Gampper (2019) investigated top UK hotels' RNRs posted on TripAdvisor. They found six moves and 18 steps, which are different from five moves and 18 steps proposed by Panseeta \& Todd (2014). A new move they found was brand positioning, which consisted of two steps: stating hotel's commitment and confirming hotel's standard. The present paper adopts Thumvichit \& Gampper's (2019) generic structure, as it is (1) the most recent one, (2) was a modification from the previous generic structure found by Panseeta \& Todd (2014), and (3) follows Swales' move-step approach.

Thumvichit \& Gampper (2019) argued that the variations in the generic structures of RNRs call for future research of RNRs generated by business and service providers in other regions. Thus, it is possible that the generic structure of RNRs may have some regional differences. Following this suggestion, the present paper attempts to identify moves and steps of RNRs, along with most frequently used expressions, written and posted on TripAdvisor by top hotels in Malang. TripAdvisor is one of the most popular websites dedicated for travel community. Containing user-generated feedback, the website represents customers' voice and "can be considered a valuable tourist text type" (Fina, 2011: 59) because they mirror what are needed and valued by customers. TripAdvisor allows hotel management to respond to each customer review. Hotel management, however, cannot remove or edit existing customer reviews.

The primary focus of the present paper is to investigate the way top hotels in Malang handle customer dissatisfaction, disappointment, and complaints that are embodied in online negative reviews. Inspired by, and following the suggestion in Thumvichit \& Gampper's (2019) study to examine hotel RNRs in different cultural setting, this paper attempts to answer two questions, First, what moves are typical to the RNRs authored by top hotels in Malang on TripAdvisor; second, what phrases and clauses are frequently used in the major moves and steps. By looking precisely at top hotels, it is expected that the findings can represent business professionalism. By focusing on one specific city, Malang, the findings can help students of business English who plan to take internships or work in hotels in the area. The generic structure of RNRs found in this study can, for example, be one of the guidelines that help them produce texts within this genre.

\section{METHOD}


The purpose of this paper is to analyze the moves and steps of RNRs generated by top ten hotels in Malang, East Java. By focusing the analysis on RNRs written by top hotels in Malang, it is expected that the patterns elicited can be a good model for learners of business English and ESP-related courses. All the RNRs were drawn from the review sections on TripAdvisor. The RNRs were retrieved from TripAdvisor from December $1^{\text {st }}$ to $6^{\text {th }} 2021$, but the RNRs were written in different years prior to the date. Thus, the results of this study should be considered only a snapshot of the period of time before 2021. Out of 311 hotels in Malang, only the RNRs produced by the hotels with highest rankings (those rank from $1^{\text {st }}$ to $10^{\text {th }}$ ) that were selected. Each hotel's homepage was then browsed through to locate the review section.

In the review section, TripAdvisor sorts the reviews into excellent, good, poor, and terrible. To make sure that the reviews were negative, poor and terrible options were ticked and reviews under belonging to these categories were chosen. Through this initial scan it was found that there were some responses that were identical. Such reviews may indicate a template, or copy-paste approach. Consequently, they are excluded from the corpus and only reviews that were specifically addressed to negative reviews were added to the corpus. Out of top ten hotels in Malang, only seven hotels received poor and terrible reviews written in English. Hence, the other three hotels were excluded from the study. Collecting a total of 29 RNRs from seven hotels in Malang resulted in a specialized corpus of 3,995 words, ranging from 41 to 254 words in each text.

An important first step in constructing a specialized corpus is to have a clearly stated research question, because it determines the design of the corpus (Reppen, 2010). The research questions of the present study are mainly about RNRs that are written by top hotels in Malang. TripAdvisor has ranked all 311 hotels in Malang. Thus, there is a need to delimit the data; what considered as 'top' hotels should be set clearly. As previously mentioned, this study investigated RNRs written by hotels that belong to the top ten. Therefore, the language data compiled to the specialized corpus are relevant and representative to the objective of this study.

Table 1. Hotel RNR Corpus 


\begin{tabular}{ccc}
\hline Name of hotel & Rank & RNRs \\
\hline A & 1 & 3 \\
B & 8 & 5 \\
C & 3 & 5 \\
D & 6 & 2 \\
E & 9 & 2 \\
F & 7 & 6 \\
G & 2 & 6
\end{tabular}

\section{Method of Analysis}

As an initial coding scheme, Thumvichit \& Gampper (2019) move structure was used as a benchmark to analyze the RNRs written by top hotels in Malang. The reason behind this decision is that not only does their framework provide detailed descriptions of both moves and steps, but also was based on previous leading study on the same topic by Panseeta \& Todd (2014). Thumvichit \& Gampper (2019) framework consists of six moves and 18 steps. While reading through the specialized corpus for several times, each expression in the RNRs was manually coded. New communicative function that emerged while coding was added to the structure, and moves or steps that are absent were excluded from the structure. Reading was done multiple times to explore and ensure the communicative function of each unit of text. Examples of moves and steps as described in studies by Zhang \& Vásquez (2014), Panseeta \& Todd (2014), and Thumvichit \& Gampper (2019) were constantly consulted and compared to the data in the specialized corpus to make sure that the labelling for moves and steps were not overlapped.

A colleague was also asked to cross-examine the coded data. The colleague has taught English in tertiary level for more than ten years, and is also familiar with Swales' notion of move analysis. Finally, the coded data were then loaded to AntConc 2.0.4, which is a software developed by Anthony (2021). This helped me elicit most frequent moves and steps, as well as the most frequent expressions that were used in the data. After several repetitive rounds of rechecking the coded data of RNRs, six move types and 23 steps were identified. There were also several frequent expressions that were typical to some moves and steps as discussed in the next section. In the following section, the examples of RNRs are written with their original spellings as they appeared in TripAdvisor. Due to ethical considerations, hotel and representatives' names are anonymized. 


\section{FINDINGS AND DISCUSSION Typical moves of RNRs}

This paper begins with the Swales' (1981) notion of "moves". A move is defined as a "discoursal or rhetorical unit that performs a coherent communicative function in a written or spoken discourse" (Swales, 2004: 288). Simply put, it is a section of a text that has a particular communicative function and goal. Texts, according to Biber \& Conrad (2009: 15), have a sequence of moves, "where each move represents a stretch of text serving a particular communicative function."

The findings of the present study revealed that the moves in RNRs written by top hotels in Malang are mostly similar to those in Thumvichit \& Gampper (2019). Their generic patterns of RNRs consist of six moves and 18 steps, while there are six moves and 23 steps found in this study. The four different steps that appeared in the data are appreciating the stay (M1C), promoting hotel's facility (M3C), clarifying misunderstanding (M4D), and making amends (M4E). Contact information (M6D in Thumvichit \& Gampper's study) was not found in the data of the present study.

Table 2. Move structure of RNRs written by 4- and 5- star hotels in Malang

\begin{tabular}{|c|c|c|}
\hline & Move & Step \\
\hline \multirow{3}{*}{ (M1) } & \multirow{3}{*}{ Opening } & $\begin{array}{ll}\text { a } & \text { Salutation }\end{array}$ \\
\hline & & b $\quad$ Greeting \\
\hline & & c Appreciating the stay \\
\hline \multirow{3}{*}{ (M2) } & \multirow{3}{*}{ Acknowledging feedback } & $\begin{array}{ll}\text { a } & \text { Expressing gratitude }\end{array}$ \\
\hline & & b Valuing feedback \\
\hline & & c Expressing regret/concern/apology \\
\hline \multirow{3}{*}{ (M3) } & \multirow{3}{*}{ Brand positioning } & a $\quad$ Stating hotel's commitment \\
\hline & & b Confirming hotel's standard \\
\hline & & c Promoting hotel's facility \\
\hline \multirow{5}{*}{ (M4) } & \multirow{5}{*}{ Dealing with complaints } & $\begin{array}{ll}\text { a } & \text { Explaining causes of incident }\end{array}$ \\
\hline & & b Reporting action taken \\
\hline & & c $\quad$ Admitting mistakes \\
\hline & & d $\quad$ Clarifying misunderstanding \\
\hline & & e Making amends \\
\hline \multirow{5}{*}{ (M5) } & \multirow{5}{*}{ Concluding remarks } & $\begin{array}{ll}\text { a } & \text { Expressing gratitude } 2\end{array}$ \\
\hline & & b Expressing regret/concern/apology 2 \\
\hline & & c Asking for a return visit \\
\hline & & d $\quad$ Soliciting direct contact \\
\hline & & e Promising to improve service \\
\hline
\end{tabular}




\begin{tabular}{lll}
\hline & & $\mathrm{a} \quad$ Sign-off \\
\cline { 2 - 2 } & Closing & $\mathrm{b} \quad$ Signature \\
\cline { 2 - 2 } & $\mathrm{c} \quad$ Job title \\
& $\mathrm{d} \quad$ Affiliation \\
\hline
\end{tabular}

\section{Move 1: Opening}

This move can be found in all responses in the corpus. RNRs typically begins with salutation (M1A) by directly addressing the customers. Salutation is mostly followed by greetings (M1B) such as "Warmest greetings from" and "Cheers from" to make the responses sound more welcoming. Up to this point, these findings agree with Panseeta \& Todd (2014) and Thumvichit \& Gampper (2019) study. Among the 29 RNRs, 10 of them also begin by showing appreciations to the customers for staying in the hotels. This mostly appear in a thanking expression. This step is different from expressing gratitude (M2A), because in this step the author is simply appreciating the customer's choice to stay in their hotel. Moreover, the author has not addressed any negative reviews yet. Below are some examples.

First of all, we would like to thank you for choosing [A]. (Hotel A).

Thank you for staying with us, we hope our sincere service could meet your expectation.

$($ Hotel F)

\section{Move 2: Acknowledging feedback}

In this second move, the author of RNRs begin addressing the customers' complaints, by expressing gratitude (M2A), valuing feedback (M2B), or expressing regret/concern/apology (M2C). Almost all RNRs contain at least two steps out of the three. When expressing gratitude (M2A), the authors of RNRs explicitly thank the customers for their reviews. This could imply a positive image of the hotels, as they are open to any feedback from customers. Some common expressions for this step are as below.

\section{Thank you for your valuable comments. (Hotel F)}

Thank you very much for your time to give your review upon your staying in Hotel

$[G]$ days ago. (Hotel $G)$

Valuing feedback (M2B) is also apparent in the RNRs, although relatively small in frequency $(\mathrm{N}=8)$. In contrast, expressing regret/apology $(\mathrm{M} 2 \mathrm{C})$ is more frequently found among the RNRs $(\mathrm{N}=25)$. Some apology expressions in the RNRs are general, not 
addressing a specific problem. However, some other include a restatement of the problem. Below are some examples.

Our <most sincerest> apology for the glitch regarding the welcome massage.

(Hotel G)

We apologize we did not meet your expectations on this occasion with your room arrangement. (Hotel B)

The tendency to employ thanking and apologizing in the RNRs under study are in line with the findings from Zhang \& Vásquez (2014) study. According to them, these frequent steps characterize RNRs as highly formulaic.

\section{Move 3: Brand positioning}

The third move, brand positioning, was present in Thumvichit \& Gampper (2019) generic structure, but absent in Zhang \& Vásquez (2014) and Panseeta \& Todd (2014) study. As for the present paper several instances of this move consist of three steps: stating hotel's commitment (M3A), confirming hotel's standard (M3B), and promoting hotel's facility (M3C).

Stating hotel's commitment (M3A) and confirming hotel's standard (M3B) are in line with the findings of Thumvichit \& Gampper (2019). According to them, these steps are a useful strategy for building "a positive mental image about the hotel" (p. 7). Below are few examples taken from the corpus.

We strive very hard each and every day to provide all of our guests with the very best experience possible. (M3A-Hotel E)

... for sure this is not a part of our standard in serving our valuable guest.

(M3B-Hotel F)

The third step within this move is promoting hotel's facility (M3C). This step is absent in the generic structure proposed by the abovementioned studies. As its name suggests, some authors of the RNRs embedded information about hotel's programs and events in their replies to the negative reviews with the aim to promote their hotels. This particular finding is explained by Liu et al. (2020): "From the perspective of social capital, if we regard the buyer's negative reviews are a crisis of the brand, the seller's response is a process of turning crisis into opportunity and solving the problem." The authors of the 
following example of RNRs strategically turn crisis as caused by negative complaints into an opportunity to promote hotel interior and events.

For your reference, in fact each of our rooms has different kinds of ambiance.

$($ Hotel $G)$

Not <loosing > its heritage and colonial look, we are a boutique hotel ... with a fresh modern interior uplift. (Hotel E)

We are regularly present the food promotion with thematic theme along the days that we wish you have enjoyed during your visit. (Hotel G)

\section{Move 4: Dealing with complaints}

The fourth move is dealing with complaints, which "plays the leading role in image protection and service recovery" (Thumvichit \& Gampper, 2019, p. 7). This move is the key part in RNRs, because this is where hotels actually tackle the issues pointed out by the customers in their reviews. This move consists of five steps: explaining causes of incident (M4A), reporting action taken (M4B), admitting mistakes (M4C), clarifying misunderstanding (M4D), and making amends (M4E). It is important to note that not all steps were present in each RNR. Rather, each RNR employs at least one of these steps in handling customer negative reviews. While the first three steps are in line with the abovementioned studies, the last two steps were added to the generic structure of RNRs in this study.

In explaining causes of incident (M4A), the authors of RNRs make attempt to explain what has been the source of problem. This function is apparent in the following example.

Indeed the check-in time was very challenging as we were running back to back with another group who checked out just before your group. (Hotel C).

While reporting action taken (M4B) functions to inform customers about the actions that hotels have taken to solve the issues, admitting mistakes (M4C) allows hotels to appear more genuine in their apologies. It is also different from expressing apology (M2C), because "only admitting mistakes is considered as the step that provides a genuine apology." Below are few examples of both steps.

This problem has been noted and we will try to improve (M4B, Hotel A) 
... that on this occasion it seemed that we had really failed to provide you with the true service excellence and Indonesian hospitality. (M4C, Hotel G)

Clarifying misunderstanding (M4D) is found when the complaints made by customers were due to miscommunication between hotels and customers. In this communicative unit, hotels are not entirely wrong and customers are note entirely right. This step is different from explaining causes of incident (M4A), because in explaining the causes of incident, there is usually a mistake committed by hotels. The examples of this step are as below.

This is just an <explanations> and it doesn't take us out of our responsibility, it just to give key to understand better the exact condition and context. (Hotel C)

The things that you <you> might think is a camera - as in fact it is an emergency lamp on the ceiling. (Hotel G)

Making amends (M4E) as found in the present study is surprising, as it is probably the most obvious way of protecting image and recovering service. It shows the extent to which hotels are willing to take responsibility of any inconvenience felt by customers. Out of 29 RNRs, this step is found in only three instances. Below are the examples.

We hope you will give us an opportunity to apologize properly and <providing> you with a wow experience we are known for. Please feel free to contact me directly at [email] so I can take care of your preferences and special [hotel G] arrangements. (Hotel G)

The fact that the step is immediately followed by soliciting direct contact (M5D) helps the RNR appear genuine and serious in their apology. Another example that is more obvious in making a compensation for customers is exemplified by the following sample.

.... your next stay will be on us. (Hotel D).

\section{Move 5: Concluding remarks}

In this fifth move, the following steps were detected: expressing gratitude 2 (M5A), expressing regret/concern/apology 2(M5B), asking for a return visit (M5C), soliciting direct contact (M5D), and promising to improve service (M5E). According to Thumvichit \& Gampper (2019), this move indicated the ending of the RNRs and authors strive to leave positive impression through this final move. One major step among these five steps is asking 
for a return visit (M5C), which appear in all 29 RNRs. This step can be seen in the examples below.

We are ever keen to welcome you again to our property. (Hotel D)

We look forward to welcoming you back soon to experience [Hotel E]. (Hotel E)

\section{Move 6: Closing}

The ending of RNRs is indicated by this $6^{\text {th }}$ move. To some extent, RNRs has a similar style with a formal business correspondence (Thumvichit \& Gampper, 2019), particularly in the opening and closing. The steps in this move include: sign off (M6A), signature (M6B), job title (M6C), and affiliation (M6D). Thumvisit \& Gampper (2019) generic structure include one more step, that is, contact information, which cannot be found in the data of the present study. It is worth noting that signature is more frequent $(\mathrm{N}=18)$ compared to affiliation $(\mathrm{N}=7)$ in the RNRs written by top hotels in Malang. Zhang \& Vásquez (2014) argued that the use of affiliation in closing pleasantries depicts a collective, corporate identity. As argued by Downing (2020), hotels have divergent communicative styles which reflect their social realities and images. The higher frequency of signature (M6B) in the present study may indicate that the authors are entirely responsible with their claims, but it can also be attributed to personal authorial style.

\section{CONCLUSION}

Responses to Negative Reviews (RNR) are not merely casual interaction between business and customers (Thumvichit \& Gampper, 2019). For hotel businesses, RNRs play a major role in determining their image and show how serious and committed they are in handling customers' complaints. Since the quality of the responses written by hotel representatives reflect the degree of hotel's professionalism (Thumvichit, 2016), RNRs are an important genre to look at, to determine the extent to which top hotels' representatives address their customers' concerns and complaints.

This paper has looked into 29 RNRs produced by seven 4- and 5-star hotels in Malang. The findings reveal that there are some differences in the generic structure of the RNRs produced by the hotels in Malang compared to previous studies (e.g. Thumvichit \& Gampper, 2019). The differences can be seen in the four additional steps: appreciating the stay in the opening move, promoting hotel's facility in brand positioning move, and clarifying misunderstanding as well as making amends in dealing with complaints move. 
Some expressions typical to major steps have also been identified (see Appendix). It is worth noting that these expressions could possibly be influenced by the authors' personal rhetorical choices, but the results have shown that some expressions are more frequent than others. Altogether, these findings may characterize the generic structure of hotel RNRs, which is also specific to top hotels in Malang.

\section{PEDAGOGICAL IMPLICATIONS}

Business interactions have grown rapidly in various online public platforms, and business English as well as business-related ESP courses should familiarize students with conventions in online professional communication (Thumvichit \& Gampper, 2019). Being influential to sales and hotel image, hotel RNRs need to be familiarized to students, especially through hands-on trainings. Students of English for hospitality business, for instance, should be prepared for the role of responding to RNRs, because this has been one of the important duties of hotel staff. The generic structure found in this study may serve as an authentic source of learning material. Therefore, teachers of such courses can further develop classroom activities from this existing generic structure, which has been exemplified by Bathia's (1991) impressive study on business letters. In addition, in business English and business-related ESP courses, providing students with authentic material and preparing them to compose professional correspondences are essential (Thumvichit, 2016). The generic structure proposed by the present paper may be used as an initial guideline for developing manuals that can assist students compose RNRs. Producing such manuals is worth doing because it enables learners to assume professional practice when producing similar text within the genre. (Panseeta \& Todd, 2014). Such manuals are particularly helpful for students commencing their internship program at hotels.

\section{REFERENCES}

Anthony, L. (2021). AntConc (Version 4.0.2) [Computer Software]. Tokyo, Japan: Waseda University. Available from https://www.laurenceanthony.net/software.

Biber, D., \& Conrad, C. (2009). Register, Genre and Style. Cambridge University Press.

Bathia, V. K. (1991). A genre-based approach to ESP materials. World Englishes, 10(2), 153-166. https://doi.org/10.1111/j.1467-971X.1991.tb00148.x

Downing, H. R. (2020). Style variation in digital interactions: Guests and hotels in Tripadvisor reviews. Doxa Comunicacion, 31, 361-380. https://doi.org/10.31921/doxacom.n31a18 
Fina, M. E. (2011). What a Tripadvisor corpus can tell us about culture. CULTUS: The Journal of Intercultural Mediation and Communication. 4, 59-80.

Geetha, M., Singha, P., \& Sinha, S. (2016). Relationship between customer sentiment and online customer ratings for hotels - an empirical analysis. Tourism Management, 61, 43-54. http://dx.doi.org/10.1016/j.tourman.2016.12.022

Liu, G., Fei, S., Yan, Z., Wu, C., \& Tsai, S. (2020). An empirical study on response to online customer reviews and e-commerce sales: from the mobile information system perspective. Hindawi: Mobile Information System, 2020, 1-12. https://doi.org/10.1155/2020/8864764

Mauri, A. G., \& Minazzi, R. (2013). Web reviews influence on expectations and purchasing intentions of hotel potential customers. International Journal of Hospitality Management, 34(1), 99-107.

Napolitano, A. (2018). Image repair or self-destruction? a genre and corpus-assisted discourse analysis of restaurants' responses to online complaints. Critical Approaches to Discourse Analysis across Disciplines, 10(1), 135-153.

Panseeta, S. \& Todd, R. W. (2014). A genre analysis of 5-star hotels' responses to negative reviews on TripAdvisor. Reflections, 18, 1-13.

Swales, J. (1981). Aspects of Article Introductions. University of Aston.

Swales, J. (2004). Research Genres: Explorations and Applications. Cambridge University Press.

Thumvichit, A. \& Gampper, C. (2019). Composing responses to negative hotel reviews: A genre analysis. Cogen Arts \& Humanities, 6(1), 1-21. https://doi.org/10.1080/23311983.2019.1629154.

Thumvichit, A. (2016). A Genre Analysis of Hotel Responses to 'Positive Reviews': Evidence from TripAdvisor.com. The 2016 WEI International Academic Conference Proceedings. Barcelona, Spain.

Zhang, Y. \& Vásquez, C. (2014). Hotels' responses to online reviews: Managing consumer dissatisfaction. Discourse, Context and Media, 6, 54-64. http://dx.doi.org/10.1016/j.dcm.2014.08.004

\section{APPENDIX}

The major moves and steps of RNRs written by the hotels in Malang, along with the examples of the most frequent expressions typical to the steps.

\begin{tabular}{|c|c|c|c|}
\hline Move & Step & Common & pressions \\
\hline \multirow{6}{*}{ (M1) Opening } & Salutation & $(M r / M r s ? M s)$ & name/ username \\
\hline & \multirow{2}{*}{ Greeting } & (Warmest) Greetings from & name of hotel \\
\hline & & Cheers from & name of hotel \\
\hline & \multirow{3}{*}{$\begin{array}{l}\text { Appreciating the } \\
\text { stay }\end{array}$} & (I/We would like to) thank & choosing us/ name of hotel \\
\hline & & you for & staying with us \\
\hline & & $\begin{array}{l}\text { We are / I am happy/ pleased } \\
\text { to hear }\end{array}$ & $\begin{array}{l}\text { that you stayed/ enjoyed/ } \\
\text { appreciated }+ \text { [positive } \\
\text { features] }\end{array}$ \\
\hline \multirow{2}{*}{$\begin{array}{l}\text { (M2) } \\
\text { Acknowledging } \\
\text { feedback }\end{array}$} & \multirow{2}{*}{ Expressing gratitude } & \multirow{2}{*}{$\begin{array}{l}\text { (I/We would like to) thank } \\
\text { you for }\end{array}$} & $\begin{array}{l}\text { sharing your review/ } \\
\text { concerns }\end{array}$ \\
\hline & & & $\begin{array}{l}\text { taking time to leave us } \\
\text { review }\end{array}$ \\
\hline
\end{tabular}


(M3) Brand positioning

\begin{tabular}{l} 
Valuing feedback \\
\hline \\
Expressing regret/ \\
concern/ apology
\end{tabular}

\section{Stating hotel's} commitment

ogy

\begin{tabular}{l} 
Your review/feedback is \\
\hline I am delighted to read \\
Without your feedback
\end{tabular}

It's been

regretful/unfortunate (to recognize/ read) that

Words cannot express

(First of all) We do/ would like to (deeply) apologize

\begin{tabular}{l} 
We are very sorry \\
\hline Please accept our (deepest) \\
apology \\
It would be (completely) \\
against our mission to \\
We are very concerned to
\end{tabular}

It is our commitment to ensure that

your honest/valuable

feedback/ review helpful/ important valuable feedback we won't be able to improve you were leaving with negative impressions [object/service] + didn't meet your expectation how sorry we are for (any) inconvenience that you didn't feel satisfied/ happy to hear about your recent experience for what happened to you [action] + intentionally the attention to details in our service and facilities [action] will note re-occur in the future

We + [name of standard/action] + every day

Confirming hotel's

(For sure) this is not a part of in serving our (valuable)

standard our standard guests

For your reference, our room/hotel/garden has

In fact, $+\quad$ [name of facilities]

Promoting hotel's facility

An example of our (environmentalfriendly) facility is + [name of facilities]

\begin{tabular}{|c|c|c|c|}
\hline & & & [name of facilities] \\
\hline & & We regularly have/present & [name of hotel events] \\
\hline & & (Firm) action & has been taken \\
\hline & Reporting action & & brought up to our attention \\
\hline & taken & The issues/ your comments & taken very seriously \\
\hline & & & noted carefully \\
\hline (M4) Dealing with & Clarifying & $\begin{array}{l}\text { The things that you might } \\
\text { think is .... }\end{array}$ & $\begin{array}{l}\text { is actually/ in fact + } \\
\text { [clarification] }\end{array}$ \\
\hline complaints & misunderstanding & This is just an explanation .... & $\begin{array}{l}\text {... to (better) understand } \\
\text { the exact condition }\end{array}$ \\
\hline & Making amends & $\begin{array}{l}\text { We would love to }+ \\
\text { amends }+ \text { on your next visit } \\
\ldots\end{array}$ & $\begin{array}{l}\text {... so we could arrange a } \\
\text { specia/better }+ \text { amends for } \\
\text { you }\end{array}$ \\
\hline & & Your next stay will be on us. & \\
\hline & Asking for a return & We look forward & $\begin{array}{l}\text { to welcoming back to our } \\
\text { hotel }\end{array}$ \\
\hline (M5) Concluding & visit & We are keen & $\begin{array}{l}\text { to welcome you again for } \\
\text { your next visit }\end{array}$ \\
\hline & Promising to & We assure & $\begin{array}{l}\text { you will have an excellent } \\
\text { service }\end{array}$ \\
\hline & & We will make sure & to serve the best service \\
\hline (M6) Closing & Sion-off & Warm regards/ Our warmest & ards \\
\hline (MI) Closing & Sign-olt & Kindest/ Best regards & \\
\hline
\end{tabular}

